\title{
A Patient with Dual Ectopic Thyroid Starting Thyroid Hormone Replacement Therapy at Age 25 Years
}

\section{Tomoyo Itonaga and Yukihiro Hasegawa*}

Division of Endocrinology and Metabolism,Tokyo Metropolitan Children's Medical Center, 2-8-29 Musashidai, Fuchu-city, Tokyo 183-8561, Japan

\section{Abstract}

Publication History:

In pediatric patients, ectopic thyroid, a form of congenital hypothyroidism, is commonly detected during neonatal mass screening. A variety of clinical manifestations of ectopic thyroid have been reported. We present herein a patient with dual ectopic thyroid showing an atypical clinical course, who was observed over a long-term follow-up period. The patient, an 8-year-old female, received the diagnosis of ectopic thyroid after a mass in her anterior neck was analyzed. Initially, her thyroid function was normal. Imaging data revealed an ectopic thyroid at the lingual root and on the thyroid cartilage. The patient showed late-onset hypothyroidism. The mass gradually enlarged (to $3 \mathrm{~cm}$ in length and $4 \mathrm{~cm}$ in width) until age 25 year when the patient's TSH level increased. The peak TSH level at the TRH test

Received: October 15, 2017 Accepted: December 14, 2017 Published: December 16, 2017

\section{Keywords:}

Hypothyroidism, Neonatal mass screening, Thyroid dysgenesis was $40.1 \mu \mathrm{U} / \mathrm{ml}$. Thyroid hormone replacement therapy was started. Ectopic thyroid should be carefully followed-up even when asymptomatic because the clinical course may be late-onset, especially in patients with dual ectopic thyroid.

\section{Introduction}

Ectopic thyroid (ET), a form of thyroid dysgenesis, is a rare developmental, congenital aberration resulting from the abnormal migration of the thyroid gland during its passage from the floor of the primitive foregut to its final pretracheal position [1,2] Thyroid dysgenesis accounts for $80-85 \%$ of permanent congenital hypothyroidism cases $(\mathrm{CH})$. Nearly $60 \%$ of thyroid dysgenesis cases are due to ET [3], which is nonetheless rare condition affecting only 1 : $100,000-300,000$ individuals in the general population $[4,5]$.

ET is detected by neonatal mass screening in some patients presenting hypothyroidism as neonates. In other cases ET is diagnosed later when signs due to enlargement of the mass, such as dysphagia, dyspnea and hemoptysis, begin to appear. A certain number of cases are also reportedly found incidentally during autopsies.

Herein we report a patient with dual ET, who started thyroid hormone replacement therapy at age 25 year.

\section{Case report}

The patient, an 8-year-old female, was referred to our hospital with the chief complaint of a mass in the anterior neck. She was the firstborn child of healthy, non consanguineous parents. A neonatal mass screening for thyroid function was negative. She had no signs due to hypothyroidism, such as developmental delay, growth failure or inactivity. At age 4 year, a mass was noted in her anterior neck, which was initially thought to be a median cervical cyst. Biopsy revealed the mass to be ET. It was monitored until age 8 year, when the mass became enlarged. The mass was soft, $1.3 \mathrm{~cm}$ in length, $2 \mathrm{~cm}$ in width, and situated on the right upper edge of the thyroid cartilage. The patient was euthyroid: the TSH level was $3.53 \mu \mathrm{U} / \mathrm{ml}$ (normal: 0.50 $5.00 \mu \mathrm{U} / \mathrm{ml}$ ) and the T4 level was $7.03 \mu \mathrm{g} / \mathrm{dl}$ (normal: 6.10-12.4 $\mu \mathrm{g} / \mathrm{dl}$ ). Both thyroglobulin antibody and anti-thyroid microsomal antibody tests were negative. CT and ${ }^{123}$ I scintigraphy revealed dual ET, i.e., the thyroid tissue was divided into two parts, one part situated in the lingual root and the other on the thyroid cartilage. ${ }^{123} \mathrm{I} 24 \mathrm{~h}$ up-take was $39 \%$ (normal: $10-40 \%$ ).

Table 1 shows the patient's clinical course. Levothyroxine (LT4) was not administered at the patient's initial visit to our hospital.
Her growth spurt began around age 9 year. Her TSH level increased to nearly $10 \mu \mathrm{U} / \mathrm{ml}$ while her T4 level remained in the normal range at age 10 year. She had menarche at age 11 year and 4 month. A TRH test was performed at age 16 year when the patient's T4 levels decreased to $6.19 \mu \mathrm{g} / \mathrm{dl}$, nearly the lower limit of the normal range. It showed no excess TSH response in spite of the mildly elevated TSH. The mass had gradually enlarged until age 25 year when the TSH level began increasing again. The cervical mass size was now $3 \mathrm{~cm}$ in length and $4 \mathrm{~cm}$ in width. The TRH tests showed the peak TSH level at the time to be $40.1 \mu \mathrm{U} / \mathrm{ml}$, which was higher compared to that at age 16 year. Therefore, LT4 $25 \mu \mathrm{g}$ was started and the volume of the mass decreased as a result of this treatment. The patient has continued to receive at the current dose of $32 \mu \mathrm{g} /$ day. The patient did not show any signs due to enlargement of the mass, such as dysphagia or dyspnea, until she reached the age of 35 years.

\section{Discussion}

Our patient passed neonatal mass screening for negative and showed late-onset hypothyroidism. The high level of TSH and enlargement of the mass in the anterior neck improved after low-dose thyroid hormone replacement therapy was begun at age 25 year.

The clinical manifestations of ET are quite variable (Table 2) [59]. The age range at diagnosis is wide ( 2 month to 85 year). Most ET cases present as a single mass in the lingual position with no other thyroid tissue, but $9 \%$ of cases present dual ET [10], as in our patient. Interestingly these data were mostly reported from countries where mass screening was not done, suggesting the majority of ET cases could have been detected using a neonatal screening test. However, the results of the screening test in our patient were negative.

"Corresponding Author: Dr. Yukihiro Hasegawa, Division of Endocrinology and Metabolism,Tokyo Metropolitan Children's Medical Center, 2-8-29 Musashidai, Fuchu-city, Tokyo 183-8561, Japan; E-mail: yhaset@gmail.com

Citation: Itonaga T, Hasegawa Y (2017) A Patient with Dual Ectopic Thyroid Starting Thyroid Hormone Replacement Therapy at Age 25 Years. Int J Pediatr Neonat Care 2: 131. doi: https://doi.org/10.15344/2455-2364/2017/131

Copyright: (c) 2017 Itonaga et al. This is an open-access article distributed under the terms of the Creative Commons Attribution License, which permits unrestricted use, distribution, and reproduction in any medium, provided the original author and source are credited. 
Citation: Itonaga T, Hasegawa Y (2017) A Patient with Dual Ectopic Thyroid Starting Thyroid Hormone Replacement Therapy at Age 25 Years. Int J Pediatr Neonat Care 2: 131. doi: https://doi.org/10.15344/2455-2364/2017/131

Page 2 of 3

\begin{tabular}{|c|c|c|c|c|c|c|c|}
\hline \multirow{2}{*}{ Age } & \multirow[b]{2}{*}{$\begin{array}{l}\text { Height } \\
(\mathrm{cm})\end{array}$} & \multicolumn{3}{|c|}{ Thyroid function test } & \multirow{2}{*}{$\begin{array}{c}\text { TRH test } \\
\text { Peak TSH } \\
(\mu \mathrm{U} / \mathrm{ml})\end{array}$} & \multirow{2}{*}{$\begin{array}{l}\text { Mass size } \\
(\mathrm{cm})\end{array}$} & \multirow{2}{*}{$\begin{array}{c}\text { LT4 } \\
(\mu \mathrm{g} / \text { day })\end{array}$} \\
\hline & & $\begin{array}{c}\mathrm{T} 4 \\
(\mu \mathrm{g} / \mathrm{dl})\end{array}$ & $\begin{array}{c}\text { T3 } \\
(\mathrm{ng} / \mathrm{ml})\end{array}$ & $\begin{array}{c}\text { TSH } \\
(\mu \mathrm{U} / \mathrm{ml})\end{array}$ & & & \\
\hline 8 year & 124 & 7.03 & 1.60 & 3.53 & & $1.3 \times 2$ & \\
\hline 10 year & 141 & 6.87 & 1.44 & 9.78 & & & \\
\hline 14 year & & 6.08 & 1.19 & 3.72 & & & \\
\hline 16 year & 155 & 6.19 & 1.39 & 6.21 & 34.28 & $3 \times 3$ & \\
\hline 25 year & 155 & 6.69 & 0.89 & 6.31 & 40.13 & $3 \times 4$ & start 25 \\
\hline 27 year & 155 & 7.13 & 0.76 & 2.12 & & & Up to 32 \\
\hline 29 year & 155 & $\begin{array}{c}\mathrm{fT} 41.22 \\
\mathrm{ng} / \mathrm{ml}\end{array}$ & $\begin{array}{c}\mathrm{fT} 33.06 \\
\mathrm{pg} / \mathrm{ml}\end{array}$ & 2.24 & & & 32 \\
\hline
\end{tabular}

Table 1. Clinical and laboratory data of the patient.

Reference ranges: TSH 0.50-5.00 $\mu \mathrm{U} / \mathrm{ml}, \mathrm{T} 46.10-12.4 \mu \mathrm{g} / \mathrm{dl}$, T3 0.80-1.60 ng/ml.

\begin{tabular}{|c|c|c|c|c|c|}
\hline & Yoon et al. [5] & Gu et al. [6] & Patil et al. [7] & Gopal et al. [8] & Total \\
\hline Number & 49 & 42 & 17 & 36 & 144 \\
\hline Sex (Male: Female) & $6: 43$ & $7: 35$ & $2: 15$ & $14: 22$ & $29: 115$ \\
\hline \multicolumn{6}{|l|}{ Age } \\
\hline$<10$ Year & 13 & 2 & 7 & ND & $(22)$ \\
\hline 10-29 Year & 26 & 11 & 8 & ND & $(45)$ \\
\hline$>=30$ Year & 10 & 29 & 2 & ND & $(41)$ \\
\hline (range) & $1 y-29 y$ & $6 y-85 y$ & $2 \mathrm{~m}-50 \mathrm{y}$ & $5 \mathrm{~m}-40 \mathrm{y}$ & \\
\hline \multicolumn{6}{|l|}{ Location } \\
\hline Lingual & 23 & 27 & 4 & 17 & 71 \\
\hline Dual & 7 & 5 & 1 & 0 & 13 \\
\hline Others & 19 & 10 & 12 & 19 & 60 \\
\hline \multicolumn{6}{|l|}{ Symptoms } \\
\hline Mass & 20 & 25 & & 19 & 64 \\
\hline Others & 29 & 17 & & 17 & 63 \\
\hline \multicolumn{6}{|l|}{ Thyroid function } \\
\hline Euthyroid & 16 & 8 & 0 & 6 & 30 \\
\hline Hypothyroid & 26 & 7 & 16 & 30 & 79 \\
\hline
\end{tabular}

Table 2: A Summary of clinical manifestations of ectopic thyroid.

There have been several reports on the onset of dual ET. Agarwal, et al. reported a case of late-onset dual ET as in our patient [11]. Meng, et al. reported that hypothyroidism in dual ET was late-onset and mild. In dual ET, the age at onset tends to be higher (14.33 \pm 8.69 vs $2.45 \pm 1.11$ year; $\mathrm{p}<0.01)$, the free $\mathrm{T} 4$ levels tend to be higher $(12.07 \pm$ 2.45 vs $7.78 \pm 2.76 \mathrm{pmol} / \mathrm{l}$ (normal: $11.50-23.50 \mathrm{pmol} / \mathrm{l}) ; \mathrm{p}<0.01$ ), and the TSH levels tend to be lower $(22.17 \pm 25.97$ vs $98.68 \pm 59.98 \mu \mathrm{U} / \mathrm{ml}$; $\mathrm{p}<0.01)$ compared to single ET [4]. Theoretically, thyroid function in ET depends on the volume of normal, functional thyroid tissue. Dual ET may have a larger functional thyroid tissue volume than single ET, which could explain the late-onset of hypothyroidism as seen in our patient. Indeed the present case showed an enlargement of the ET of the neck during puberty when the demand for thyroid hormone, in general, increases. Her subclinical hypothyroidism continued and thyroid hormone replacement therapy was started from the age of 25 year.

The differential diagnosis of the enlarged mass in our case was modular goiter, adenoma, Hashimoto's thyroiditis, colloid goiter, and thyroid cysts, which can occur in the ectopic thyroid glands as well as in the orthotropic thyroid gland and lead to thyroid dysfunction [6]. However, these possibilities were low since the thyroid antibodies were negative in our case and the mass size correlated with the TSH level and decreased after replacement therapy was begun.

In conclusion, the ectopic thyroid should be carefully followedup even when asymptomatic because the clinical course can be lateonset, especially in patients with dual ET.

\section{Competing Interests}

The authors declare that they have no competing interests.

\section{Reference}

1. Di Benedetto V (1997) Ectopic thyroid gland in the submandibular region simulating a thyroglossal duct cyst: a case report. J Pediatr Surg 32: 17451746.

2. Babazade F, Mortazavi H, Jalalian H, Shahvali E (2009) Thyroid tissue as a submandibular mass: a case report. J Oral Sci 51: 655-657. 
Citation: Itonaga T, Hasegawa Y (2017) A Patient with Dual Ectopic Thyroid Starting Thyroid Hormone Replacement Therapy at Age 25 Years. Int J Pediatr Neonat Care 2: 131. doi: https://doi.org/10.15344/2455-2364/2017/131

Page 3 of 3

3. Eugene D, Djemli A, Van Vliet G (2005) Sexual dimorphism of thyroid function in newborns with congenital hypothyroidism. J Clin Endocrinol Metab 90: 2696-2700.

4. Meng Z, Lou S, Tan J, Jia Q, Zheng R, et al. (2014) Scintigraphic detection of dual ectopic thyroid tissue: experience of a Chinese tertiary hospital. PLoS One 9: e95686.

5. Yoon JS, Won KC, Cho IH, Lee JT, Lee HW, et al. (2007) Clinical characteristics of ectopic thyroid in Korea. Thyroid 17: 1117-1121.

6. Gu T, Jiang B, Wang N, Xia F, Wang L, et al. (2015) New insight into ectopic thyroid glands between the neck and maxillofacial region from a 42-case study. BMC Endocr Disord. 15: 70.

7. Patil M, Ayyar V, Bantwal G, Raman A, George B, et al. (2015) Thyroid ectopia: A case series and literature review. Thyroid Research and Practice 12: 110-115.

8. Gopal RA, Acharya SV, Bandgar T, Menon PS, Marfatia H, et al. (2009) Clinical profile of ectopic thyroid in Asian Indians: a single-center experience. Endocr Pract. 15: 322-325.

9. Pierro A, Cilla S, Modugno P, Sallustio G (2017) Incidental Finding of Dual Ectopic Thyroid on Computed Tomography Angiography. J Clin Imaging Sci. 7: 30.

10. Wildi-Runge S, Stoppa-Vaucher S, Lambert R, Turpin S, Van Vliet G, et al. (2012) A high prevalence of dual thyroid ectopy in congenital hypothyroidism: evidence for insufficient signaling gradients during embryonic thyroid migration or for the polyclonal nature of the thyroid gland? J Clin Endocrinol Metab. 97: E978-E981.

11. Agarwal KK, Karunanithi S, Jain S, Tripathi M (2014) A case of dual ectopy thyroid along the thyroglossal tract demonstrated on $99 \mathrm{mTc}$-Pertechnatate hybrid single photon emission computed tomography/computed tomography. Indian J Nucl Med. 29: 105-107. 